ISSN (print): 1698-6180. ISSN (online): 1886-7995

www.ucm.es/info/estratig/journal.htm

Journal of Iberian Geology 38 (1) 2012: 113-126

http://dx.doi.org/10.5209/rev_JIGE.2012.v38.n1.39208

\title{
Recent tectonic model for the Upper Tagus Basin (central Spain)
}

\author{
Modelo tectónico reciente de la Cuenca Alta del Tajo (parte central española)
}

\author{
J.L. Giner-Robles*1, R. Pérez-López ${ }^{2}$, P.G. Silva ${ }^{3}$, A. Jiménez-Díaz ${ }^{4}$, M.A. Rodríguez-Pascua ${ }^{2}$ \\ ${ }^{1}$ Dpto. Geología y Geoquímica. Facultad de Ciencias. Campus de Cantoblanco, Universidad Autónoma de Madrid. \\ 28049-Madrid, Spain.jorge.giner@uam.es \\ ${ }^{2}$ IGME - Instituto Geológico y Minero de España. Área de Investigación y Peligrosidad en Riesgos Geológicos C/ \\ Ríos Rosas 23, 28003 Madrid, Spain r.perez@igme.es,ma.rodriguez@igme.es \\ ${ }^{3}$ Dpto. Geología, Escuela Politécnica Superior de Ávila, Universidad de Salamanca. Avda. Hornos Caleros, 50. \\ 05003-Ávila.España.Email:pgsilva@usal.es \\ ${ }^{4}$ Dpto. de Geodinámica. Facultad de Ciencias Geológicas. Universidad Complutense de Madrid. 28040 - Madrid. \\ España (Spain).Email: ajimenezdiaz@geo.ucm.es
}

*Corresponding author

Received: 08/12/2011 / Accepted: 08/03/2012

\begin{abstract}
Active tectonics within the Upper Tagus Basin is related to the lithospheric flexure affecting the Palaeozoic basement of the basin. This flexure displays NE-SW trending. Besides, this structure is in agreement with the regional active stress field defined by the maximum horizontal stress with NW-SE trending. In this tectonic framework, irregular clusters of instrumental seismicity (Mw $<$ 5.0) fade in the zone bounded by the Tagus River and the Jarama River valleys. These clusters are related to major NW-SE trending faults of suspected strike-slip kinematics. Moreover, reverse faults with NE-SW trending are affected by the strike-slip system as well. Despite the reverse faults are in agreement with the present SHMAX orientation, though, they apparently are blocked as seismogenic sources (scarce instrumental seismicity recorded today). In addition, we have determined the regional and local stress/ strain fields and two different fracture patterns were observed. Hence, we have divided the area in two zones: (1) the lateral bands of the basin, defined by reverse faulting (NE-SW trending) and strike-slip faulting (NW-SE trending) and (2) the central zone of the basin characterized by shallow normal faulting and NE-SW trending strike-slip faults. Furthermore, surface faulting and liquefaction structures are described affecting Middle to Late Pleistocene fluvial deposits, suggesting intrabasinal palaeoseismic activity (5.5 $<\mathrm{M}<6.5)$ during the Late Quaternary. The obtained structural and tectonic information has been used to classify and characterize the Upper Tagus Basin as a semi-stable intraplate seismogenic zone, featured by Pleistocene slip-rates $<0.02 \mathrm{~mm} / \mathrm{yr}$. This value is low but it affords the occurrence of Pleistocene paleoearthquakes.
\end{abstract}

Keywords: Seismotectonics, Focal mechanisms, Paleoseismicity, Pleistocene, Upper Tagus Basin 


\section{Resumen}

La tectónica activa de la Cuenca Alta del río Tajo está caracterizada por la presencia de una flexión litosférica localizada en el basamento paleozoico, y cuyo eje se orienta según NE-SW. Esta flexión es coherente con el estado de esfuerzos actual en la zona, definido mediante la orientación del esfuerzo máximo horizontal, SHMAX, según NW-SE. En este contexto, la sismicidad en el borde sur del Sistema Central aparece concentrada en fallas direccionales según NW-SE, registrándose terremotos de magnitud $<5.0$ (S. XX). Estos desgarres sectorizan el sistema de fallas inversas (NE-SW) que estructuran la cadena montañosa, las cuales a pesar de estar orientados coherentemente con el estado actual de esfuerzos, aparecen bloqueados o desactivados como fuentes sismogénicas. La geometría de la flexura condiciona la ocurrencia de una zona de concentración anómala de esfuerzos que resulta en la agrupación de eventos sísmicos localizada entre los valles de los ríos Tajo y Jarama. El estudio sismotectónico indica que el campo actual de deformación se encuentra distribuido en dos zonas relacionadas con la flexión: (1) una zona central caracterizada por la presencia de fallas normales superficiales y desgarres orientados según NE-SW; y (2) zona lateral caracterizada por fallas de tipo inverso (NE-SW) y desgarres (NW-SE) y que bordea a la zona anterior. Estudios paleosísmicos en la zona muestran la ocurrencia de diferentes niveles de liquefacción afectando a los depósitos fluviales del Pleistoceno Medio y Superior en los valles de los ríos Manzanares, Jarama y Tajo, así como una importante variedad de estructuras de deformación. En general la granulometría licuefactada muestra diques de arena, aunque en algún caso aparecen niveles decimétricos de gravas. A partir de los datos sismotectónicos, geológicos y paleosísmicos descritos y recopilados para esta zona, la Cuenca alta del Tajo puede clasificarse como una zona sismogénica intraplaca con velocidades de deformación pleistocenas inferiores a $0,02 \mathrm{~mm} /$ año y sismicidad instrumental difusa de tamaño moderado-bajo.

Palabras clave: Sismotectónica, Mecanismos focales de terremotos, Paleosismicidad, Pleistoceno, Cuenca alta del Tajo.

\section{Introduction}

The Upper Tagus Basin (UTB) is located at the central part of the Iberian Peninsula, and include the province of Madrid, parts of the provinces of Guadalajara, Toledo, Cuenca and Segovia, and the major mountain range constituted by the Spanish Central System (SCS). The most relevant feature of the UTB to be faced by the seismic risk study is their proximity to large urban and industrial areas (i.e. Madrid, Guadalajara and Alcalá de Henares). The instrumental seismic record of the area displays small earthquakes with magnitudes $\mathrm{M}<5.0$ (www.ign. es; 1996-2011). Moreover, this instrumental seismicity in the region displays spatial and temporal clusters of smallmoderate earthquakes $(3.0<\mathrm{Mw}<5.0)$, most of them located within a NE-SW narrow band area defined by the watershed zone of the Tagus and Jarama river valleys, about $30-40 \mathrm{~km}$ SE of the Madrid city. The last significant earthquake in the zone occurred in 7 June 2007 (Escopete; Guadalajara) with a magnitude $\mathrm{mb} 4.2$ and $10 \mathrm{~km}$ depth (www.ign.es). This earthquake triggered a ground motion with a maximum PGA value of $0.071 \mathrm{~g}$ (Carreño et al., 2008). This relatively high ground response is related to the relatively thick Cenozoic sedimentary filling of the basin (up to $3 \mathrm{~km}$, i.e. Alonzo-Zarza et al., 2004; Gómez-Ortiz et al., 2005), but also the near-field effect has to be considererd (Carreño et al., 2008). The extensive ancient Late Neogene surface dominating the intrabasinal landscape, as well as the scarce evidence of recent earthquake-related deformations (Silva et al., 1997;
De Vicente et al., 2007), make difficult to assign a deformation Quaternary tectonic slip-rate for the Upper Tagus Basin (UTB). However the occurrence of deep Canyonlike valleys at basin center locations, boundend by relevant kilometric lineal scarps between 40-60 m high, related in some cases to moderate historic and instrumental seismicity (Silva et al., 1988; Silva, 2003; De Vicente et al., 2007), support the hypothesis of Late Quaternary tectonic activity in the region. Furthermore, Quaternary fluvial deposits of Middle to Late Pleistocene age, display evidence of strong fracture density, tectonic deformation and a wide variety of liquefaction structures related to synsedimentary faulting and collapse of the underlaying Neogene evaporites (Silva et al., 1988; Giner, 1996; Silva et al., 1997; Silva, 2003). Under these assumptions, the integration of both new and old data as well as the implementation of new techniques are required to perform an updated seismic hazard analysis for the UTB.

Hence, the main goal of this work is to propose a innovative interpretation of the seismic potential of the UTB by the integration of (a) paleoseismic evidence for Pleistocene deposits within the main river valleys; (b) seismotectonic data from the focal mechanism solutions and instrumental seismicity; and (c) the widespread existing structural and geological data on active faulting for the area and rheological models for the lithosphere within the basin as well.

Active faulting and Quaternary tectonics are the eventual responsible for the landscape and shaping of the SCS border, the uplift of the Neogene materials at the basin 


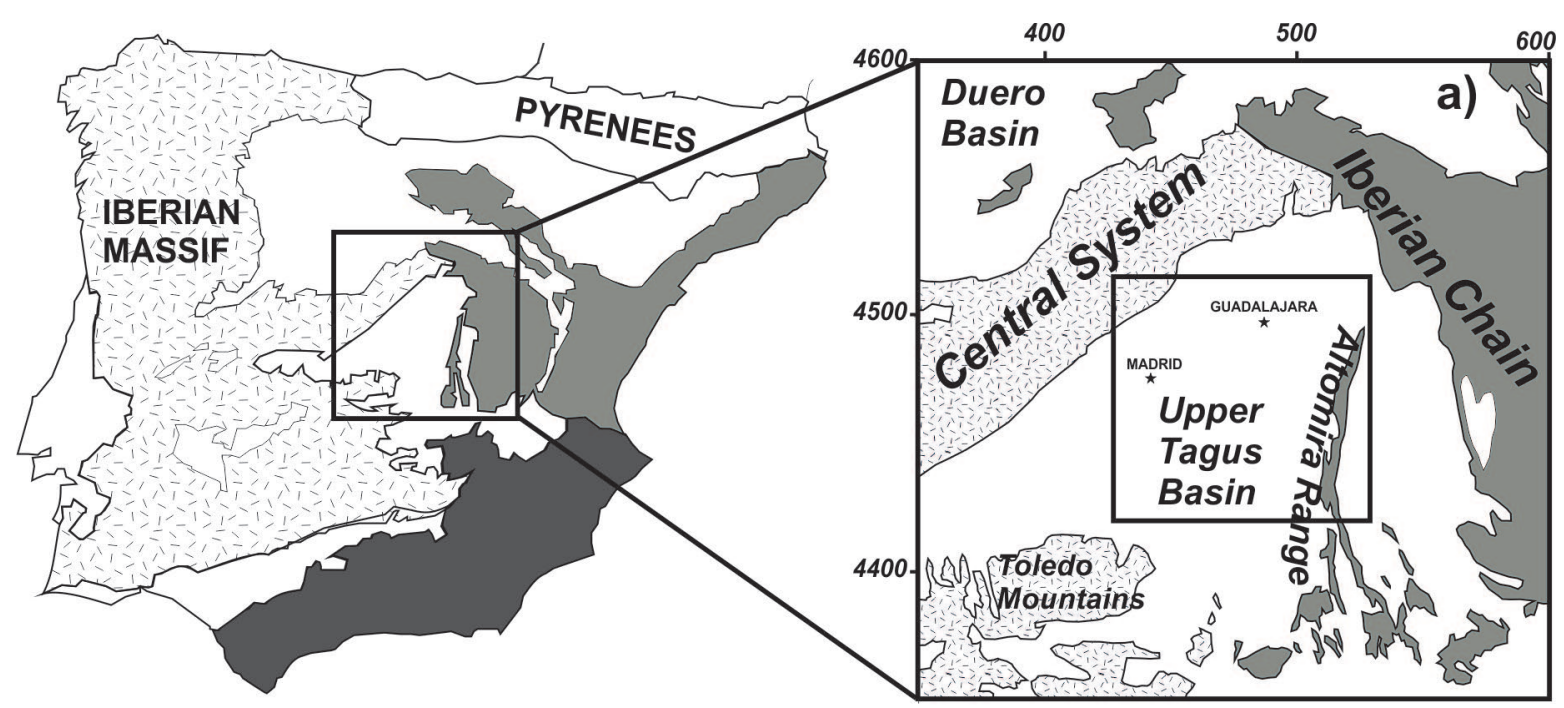

Fig. 1.- Geological setting and geographical location of the study area(little square), with the principal geological structures: Upper Tagus Basin (UTB), composed by the Spanish Central System (SCS), Altomira Range (AR) and the Toledo Mountains (TM).

Fig. 1.- Situación geológica de la zona de estudio (recuadro pequeño), con las principales unidades geológicas: Cuenca Alta del Tajo, Sistema Central, Sierra de Altomira y Montes de Toledo.

centre and the paleoseismic evidence within the valleys, with recording estimated event-magnitude of c.a. 5.5 to 6.5 , are the way to go a step beyond for the seismic hazard assesment in this zone of scarce intrumental seismicity.

\section{Geodynamic and geologic background}

The Upper Tagus Basin (UTB) covers an area of about $12,000 \mathrm{~km}^{2}$, and is located at the central part of the Iberian Peninsula, including the provinces of Madrid, Guadalajara, Toledo, Cuenca and Segovia. The basin is a complex zone of Paleogene to Neogene sedimentary infilling (Alonso Zarza et al., 2004), limited by three intracratonic mountain ranges: the Spanish Central System (SCS) to the north, the Altomira Range (AR) to the east,and the Toledo Mountains (TM) to the south (Fig.1). The SCS is interpreted as a Cenozoic pop-up controlled by E-W and NE-SW structures linked to large-scale lithospheric flexure triggered by the SE-NW far-field stress propagation of the Africa-Eurasia collision (De Vicente et al., 2007). These authors indicated that the aforementioned fault systems reach and affect to shallow crustal levels within the basin.

The topography and the crustal structure of the SCS and adjacent areas can be explained by lithospheric folding according to the analogue experimental models performed by Fernández-Lozano et al. (2011), and based on previous proposals (i.e. Giner et al., 1996 ; Cloetingh et al., 2002 ; De Vicente et al., 2007). The shallow seismicity at the intraplate western area of Iberia is explained by
Fernández-Lozano et al. (2011) as a consequence of the stress transfer from the plate boundaries to the interiors. Relationships between the topography, the Bouger anomaly, the temperature at $100 \mathrm{~km}$ depth and the temperature at the Moho, suggest a hot-zone between the SCS and the $\mathrm{TB}$, in agreement with the zone in which is presently recorded the instrumental seismicity (time-period between 1980-2010) (Fernández-Lozano et al., 2011).

The basement of the basin is composed by Variscan granitic and metamorphic rocks, with a Mesozoic and Paleogene cover (pre-tectonic Alpine unit), whilst the main infilling materials are constituted by overlaying Neogene sedimentary sequences and "cut and fill" Quaternary deposits (post-tectonic Alpine unit) related to the development of the present drainage network. In this geological framework, the main tectonic structures have a conjugate orientation, with NE-SW and NW-SE trending (Giner et al., 1996). All of these structures are related with the aforementioned lithospheric flexure defined by the basement geometry and differential filling and thickness of Neogene sequences (De Vicente et al., 1996; Giner et al., 1996; Cloetingh et al., 2002; De Vicente et al., 2007, 2009; Martín-Velázquez et al., 2009).

Thermal and rheological models for the SCS and adjacent areas were developed by Suriñach and Vegas (1988) and Tejero and Ruiz (2002), with a surface heat flow ranging between 80 and $60 \mathrm{mWm}^{-2}$, and with the Moho located at 31-34 km in depth. Jiménez-Díaz et al. (2012) suggested a value ranging between $81-83 \mathrm{mWm}^{-2}$ of the surface heat flow for the Tagus Basin, involving mantle 
processed to the continuous uplift of the SCS. Models developed by these authors indicate a maximum thickness for the upper crust of $16 \mathrm{~km}$ within the Tagus Basin and of $11 \mathrm{~km}$ for the SCS. Moreover, two crustal discontinuities, at 11 and $31 \mathrm{~km}$ depth respectively, have been described from the spectral analysis of gravity data (Gómez-Ortiz et al., 2005). In consequence, in this work is assumed the interval between 11-16 km depth as the preferred crustal level for brittle deformation and seismogenic source, in order to evaluate the area for faulting rupture according to the main Quaternary faults traces described in the following sections.

These mountain ranges display different tectonic frameworks and deformation ages, as a consequence of the evolving stress-field throughout the Cenozoic (De Vicente et al., 1996; 2007, 2009; Babín-Vich and GómezOrtiz, 1997, Martín-Velázquez et al., 2009; FernándezLozano et al., 2011). The active stress-field within the SCS is defined by the horizontal maximum stress orientation, SHMAX, NW- trending (De Vicente et al., 1996; Herraiz et al., 2000). This stress-field is still working from the Late Miocene (De Vicente et al., 1996). The stress-field promoting SCS building corresponds with an intraplate response to far-field effect from the active tectonic boundaries. Commonly, the lithospheric folding instead of mantle process is invoked to explain the active tectonic deformation and vertical movements in this zone (Cloetingh et al., 2002; De Vicente et al., 2007, 2009). Polyphase deformation from the Miocene to the present may explain the stress convergence at the SCS (Cloetingh et al., 2002). This convergence comes from the Pyrenean compression ( $\mathrm{N}$ - to NE- trending), the Betic compression (SSE-trending), the Mid-Atlantic Ocean Ridge (MAOR) push (W- trending) and the Valencia Through extension (WNW-trending). At this point, different authors explain vertical movements at SCS as result of the lithospheric folding (Giner, 1996; De Vicente et al., 1996; Cloetingh et al., 2002; De Vicente et al., 2007, 2009; MartínVelázquez et al., 2009). Since the lithospheric folding implies large-scale deformation and large wavelength in vertical movements, the active tectonic slip-rate operating in the SCS has to be estimated from Pleistocene, at least. Pérez-López et al. (2005) described the stress-field at the South Border of the SCS as strike-slip to uniaxial extension from Eocene to present. Martín-Velázquez et al. (2009) modeled this stress-field by using finite elements and a punctual rheological model obeying the thermal model of Tejero and Ruiz (2002). The relevance of this model is the simulation of the stress state at the surface of the SCS, where the present topography plays as tectonic loading for faults.
In this work, firstly, major faults with surface trace larger than $30 \mathrm{~km}$ (see Wells and Coppersmith, 1994) are recognized. Secondly, striate fault-orientation and stress agreement are studied and finally, Quaternary tectonic markers and paleoseismic evidence are described. However, fault parametrization for hazard purposes is still a controversy. In this sense, the geothermal features (Jiménez-Díaz et al., 2012), the analogue models of the lithosphere (Fernández-Lozano et al., 2011) and numerical models (Martín-Velázquez et al., 2009) underneath the SCS, could shed light on the fault width which could be load for trigger either moderates or destructive earthquakes.

\section{Neotectonic structural analysis}

\subsection{Macro-scale structural analysis}

Despite the asymmetric character of the deformation spatial distribution within the basin (De Vicente et al., 2007), the geomorphology features and lineaments interpreted from digital elevation models suggest the existence of two different fracture patterns (Fig. 2): (1) Guadarrama Fracture Pattern (GP1), mainly oriented towards NW-SE, and secondary toward NE-SW. We assume these lineaments orientations (NW-SE trending) with strike-slip faults NW-trending, and the secondary set with reverse faults with NE-trending (De Vicente et al., 1996; Giner, 1996). (2) Guadalajara Fracture Pattern (GP2): defined by lineament sets oriented towards NE-SW. This fracture pattern could be related with the local stress tensor defined by NE-trending horizontal maximum stress orientation (Giner, 1996; Giner et al., 1996). GP2 re-activates normal faults and secondary strike-slips with NE-trending. This stress field is orthogonal to the Guadarrama stress field and it is interpreted as a switch between the main axes (SHMAX, SHMIN) as a response for the basement flexure (Giner et al., 1996). Assuming these stress fields could be coeval and SHMAX and SHMIN could switch through time and thus generate the roughly orthogonal compression and extension directions.

Hence, we have divided the UTB in two subzones according to both fracture patterns described above. Figure 2 shows both areas elongated with NE-SW trending mainly located at: (a) the central subzone are in coincidence with the Tajuña River and lineaments interpreted (NE-trending). This subzone overlies the axis of the flexure of the basement, and (b) lateral subzones located at the NW and SE boundary of the basin and lineaments with NW-trending. The South boundary of the subzone 


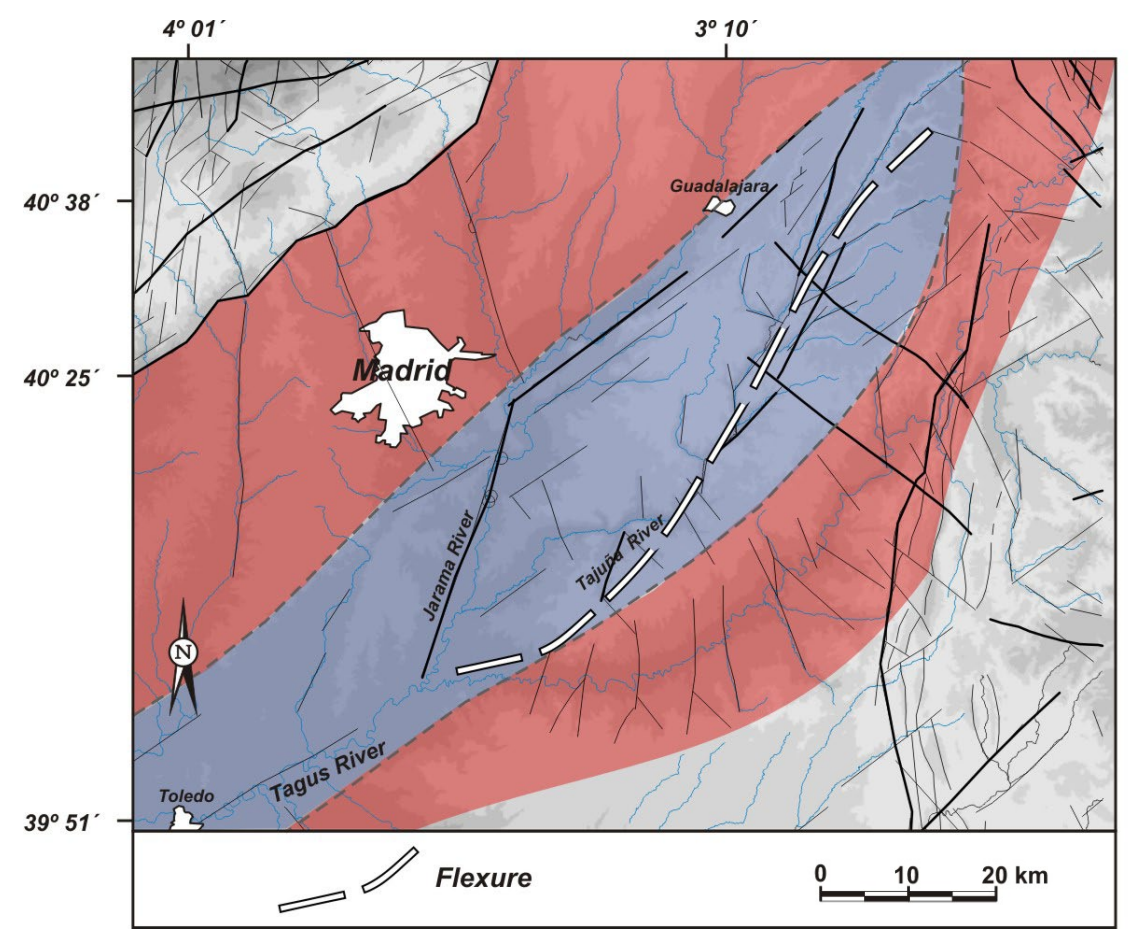

Guadalajara

Fracture Pattern (GP2)

Guadarrama

Fracture Pattern (GP21

Fig. 2 .- Spatial zonification according to fracture patterns of morpholineaments and geomorphic features. Bold lines are major faults with seismic evidence (CSN, 2007). The central zone shows faulting defined by a strain tensor with NE-trending for SHMAX. See the text for further explanation.

Fig. 2.- Sectorización de la zona en función de los patrones de fracturación definidos en el análisis macroestructural. Los morfolineamientos utilizados presentan dos categorías: fallas de primer orden, en trazo más grueso, y estructuras de segundo orden (en trazo más fino) (CSN, 2007). Se pueden definir dos zonas: una zona central caracterizada por fallas con orientación NE-SW; y dos áreas similares entre si, una al sur y otra al norte de la zona central, caracterizadas por fallas con orientaciones según NW-SE.

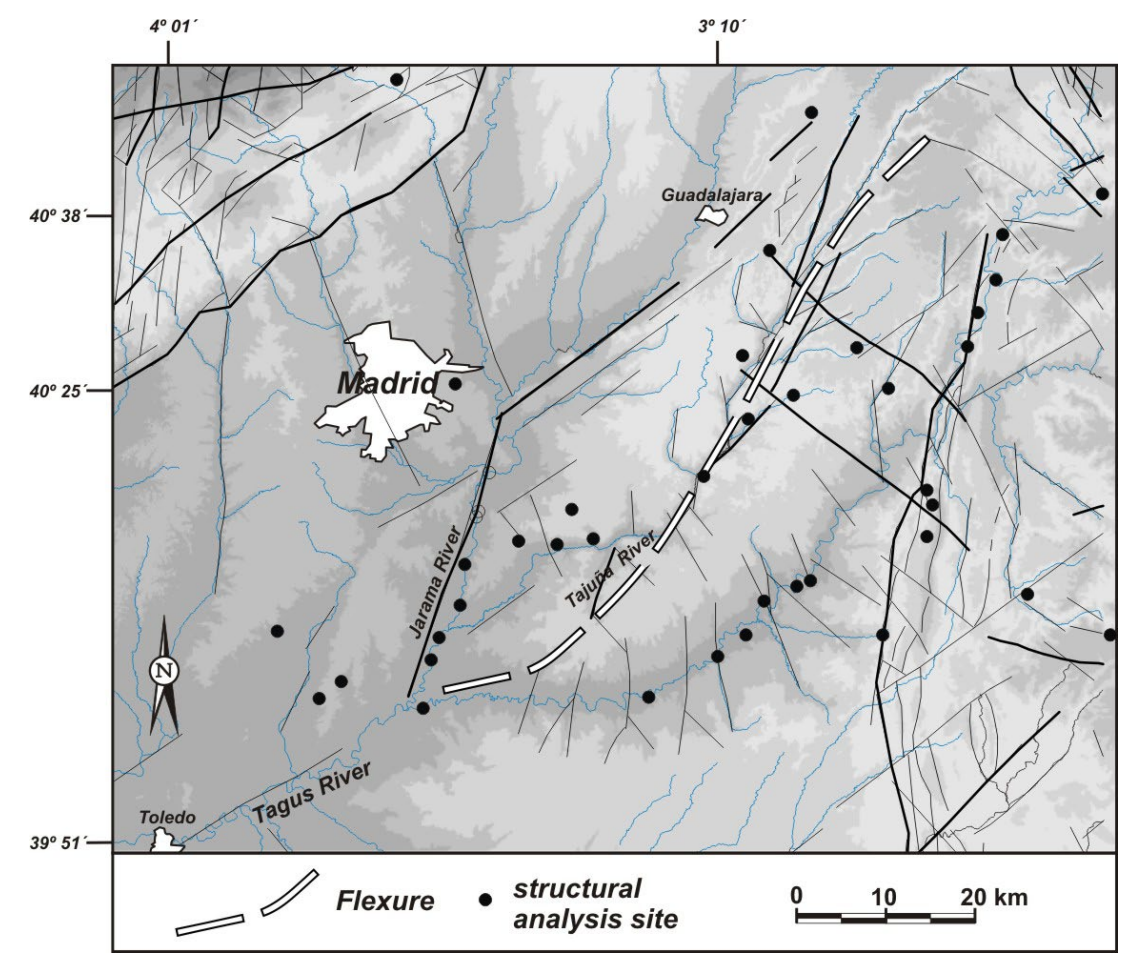

Fig. 3.- Major tectonic structures, principal rivers (blue line) and relief (red indicates mountain ranges and yellow displays valleys). Black dots are field stations of structural measurements.

Fig. 3.- Mapa esquemático de las principales estructuras tectónicas en la Cuenca de Madrid (CSN, 2007) y los principales ríos. Los círculos negros representan las estaciones de análisis estructural en las que se han podido obtener datos de orientación y forma del tensor de esfuerzos.

(b) shows evidence of Quaternary faulting and Late Quaternary syn-sedimentary deformations and paleo-liquefaction signals as well (see next section for location).

\subsection{Micro structural analysis}

Figure 3 shows the location of the 43 structural field stations for fault planes affecting Neogene and Quaternary deposits. There, we have measured more than 700
(743) kinematic data on fault planes to obtain the active stress tensor (Fig. 4). We have applied the structural analysis technique proposed by Reches (1987) to obtain the stress tensor $\left(\sigma_{1}, \sigma_{2}, \sigma_{3}\right.$ and SHMAX) from slip vectors measured on the fault planes. The results suggest the coeval existence of two stress fields:

Regional stress tensor (Fig. 5a): featured by SHMAX with NW-trending, activates strike-slips (Fig. 6) and reverse faults (Fig. 7a and 7b). 


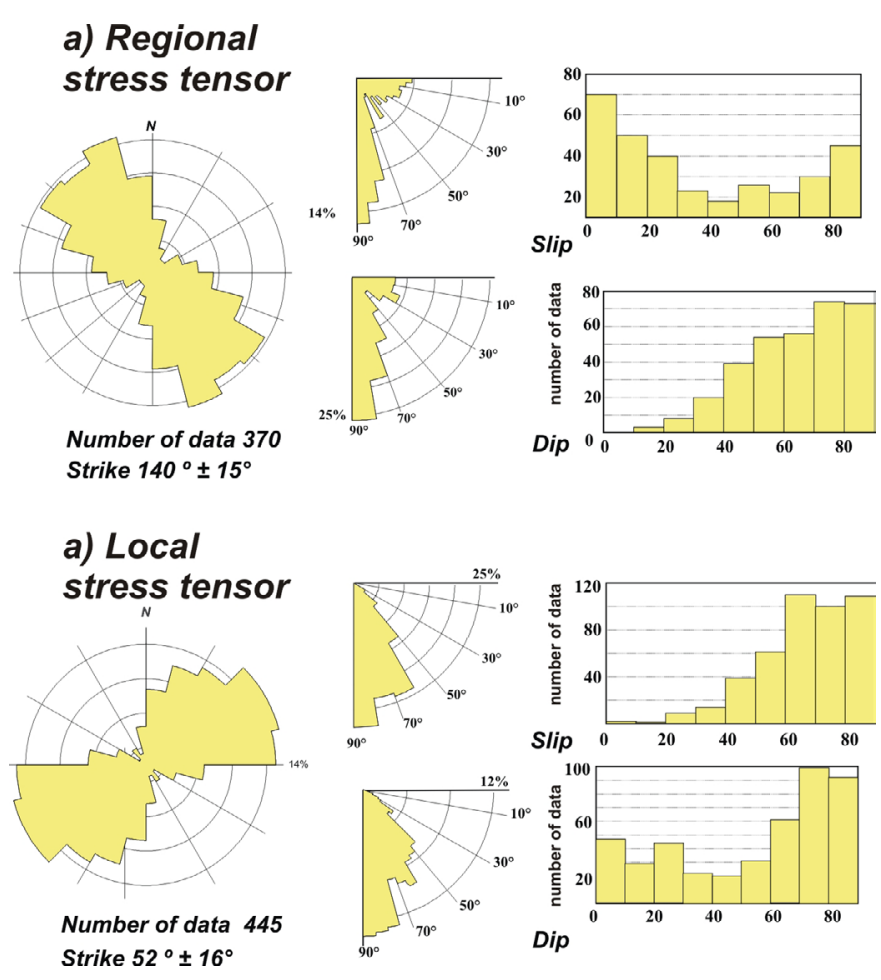

Fig. 4.- Structural data of strain tensors obtained for the analysis of slicken-sides measured on quaternary fault planes. (a) Regional stress tensor (SHMAX with NW-trending). (b) Local stress tensor (SHMAX with NE-trending). Diagrams represent fault orientation and dip and pitch of the striation.

Fig. 4.- Análisis de planos de falla estriados obtenidos en materiales del Plioceno y del Cuaternartio de la cuenca Alta del río Tajo, coherentes con (a) el tensor regional (SHMAX según NO-SE) y (b) con el tensor local (SHMAX según NE-SO). Se presentan diagramas de orientaciones y buzamientos de los planos, y de cabeceo de la estría sobre el plano de falla $\left(0-90^{\circ}\right)$.

Local stress tensor (Fig. 5b): featured by SHMAX with NE-trending, activates normal and lateral faults (Fig. 7c and 7d) (Giner et al., 1996; De Vicente et al., 1996).

The spatial distribution of the structural stations covers all the zones defined from the macro-scale structural analysis. Accordingly, we can observe that the structural stations associated with the local stress tensor are located within the central zone, Guadalajara fracture pattern (GP2) (Fig. 2 and 4) whereas the regional stress tensor is related with stations located within the Guadarrama fracture pattern (GP1). Furthermore, the spatial relationship between both deformational patterns, observed in the field stations in the south boundary of the basin, also suggests that faults activated by the local stress tensor are younger in age to those faults activated by the regional stress field.

Finally, it is necessary to note that the sedimentary infilling of the basin may enlarge the deformation recorded at surface by halokinesis of the Neogene evaporates located at basin centre locations (see Alonso Zarza et al.,
2004 for spatial location). However, the coherence and arrangement of both fault patterns, in agreement with the tectonic context of the basin, suggest a main tectonic control underneath karstic-collapses assisting large canyonvalley development in central basin locations as previously suggested by several authors (Silva et al., 1988; Giner et al., 1996; Silva, 2003; Alonso Zarza et al., 2004).

\section{The Pleistocene paleoseismic record}

Several liquefaction structures have been described within the basin (Giner et al., 1996; Silva et al., 1997; Silva 2003; Silva et al., 2010; Silva et al., 2011), related to recent faulting and with Paleolithic settlements (younger than $780 \mathrm{Ka}$ ). However, more detailed studies are required to establish a complete table of paleoseismic parameters (slip-vector, total offset, recurrence intervals, etc.). Furthermore, the most of the structures described here correspond with liquefactions, and consequently it is very difficult to assign seismic sources and recurrence intervals.

All of these paleoseismic structures are in agreement with the local stress tensor (SHMAX NE-trending) and

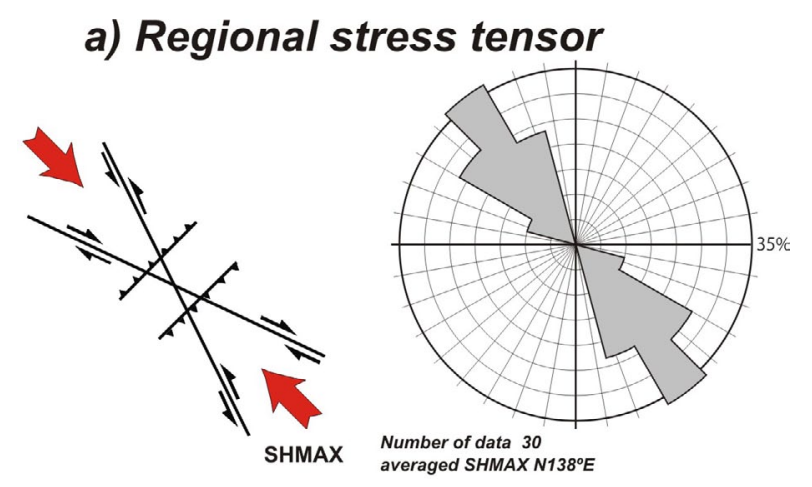

b) Local stress tensor

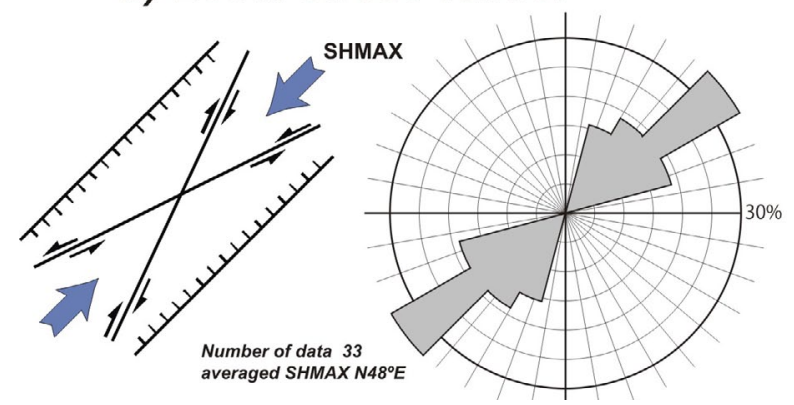

Fig. 5.- Rose diagrams for SHMAX of the stress tensors determined within the Upper Tagus Basin. (a) Regional stress tensor and (b) local stress tensor.

Fig. 5.- Resultados del análisis de esfuerzos de las estaciones de análisis estructural con datos de planos de falla estriados. Se representan la rosa de orientaciones medias de SHMAX obtenidas en cada una de las estaciones de análisis: (a) tensor regional y (b) tensor local. 
Fig. 6.- Strike-slip faulting affecting Pleistocene fluvial terraces of the Tagus River. These faults are activated by the regional stress tensor with SHMAX oriented to NW-SE.

Fig. 6.- Ejemplo de una de las estructuras de desgarre (SHMAX según NO-SE, tensor regional) en el norte de la cuenca. Las fallas afectan a materiales de terrazas del río Tajo de edad Pleistocena.

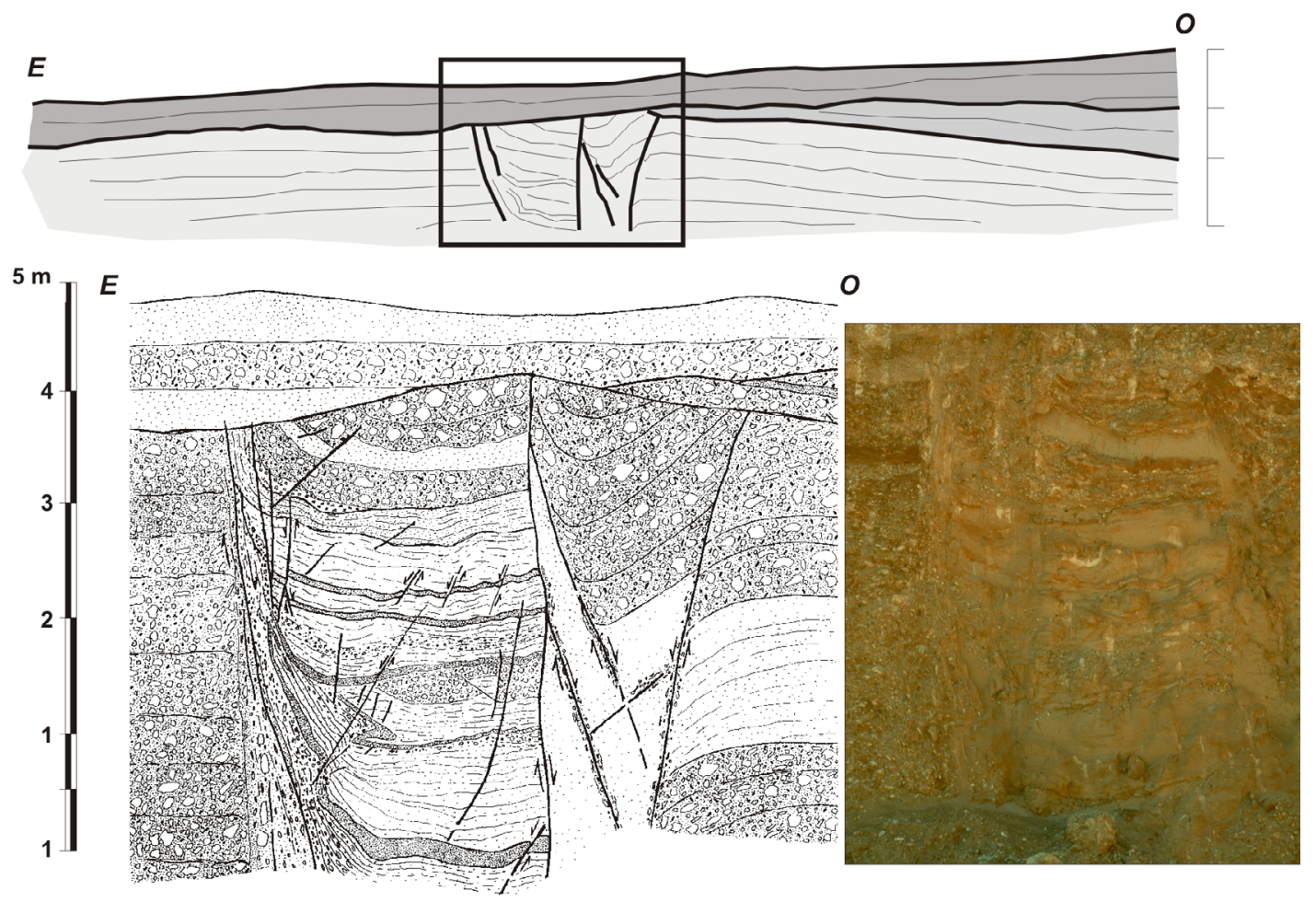

affecting mainly fluvial Middle to Late Pleistocene deposits (Fig. 8). Most of the liquefaction structures observed are sand-dikes-like mainly associated to normal and lateral faults activated by the local stress tensor (Fig. $7 \mathrm{~b}$ and $7 \mathrm{c}$ ). The nature and dimensions of these structures suggest the occurrence of paleoearthquakes with magnitudes greater than M5-M5.5, according to the proposals of Obermeier (1996) and Rodríguez-Pascua et al. (2000). In addition, there are recorded liquefaction affecting gravel deposits (Rodríguez-Pascua et al., 2000) as well as thick (0.8-1.2 $\mathrm{m}$ ) individual liquefaction horizons in medium-coarse sands (Silva et al., 2010 and 2011), suggesting paleoearthquake magnitudes greater than M6.

We have recognized liquefaction related to reverse faulting (NE-trending) as well, located at the south zone of Villarubia de Santiago town (Toledo) (Fig. 9). This fault was activated by the regional stress-tensor (SHMAX NW-trending). The liquefaction affects Middle-Late Pleistocene fluvial sediments of the Tagus River, but also all these features are common within the main tributaries such as the Jarama, Tajuña and Manzanares (Silva, 2003; Alonso Zarza et al., 2004; De Vicente et al., 2007). Sand-dikes are injected into the fault plane and the vertical throw was $0.5 \mathrm{~m}$. We assume that this liquefaction corresponds with one single event and consequently, the observed vertical offset corresponds with a coseismic vertical throw. Accordingly, empirical relationships (Wells and Coppersmith, 1994) suggest a maximum magnitude ranging between M6.4 and M6.6.

\section{Instrumental seismicity}

Anomalous clusters of seismicity are located in a narrow band between the Tagus River and the Jarama River (Fig. 10). These clusters are classified as anomalous since no Quaternary active faults have been described in this area and no seismic sources have been recognized except those in the works of Silva et al. $(1988 ; 1997)$ and Giner (1996). This zone is elongated with NE-trending in coincidence with the axis of the basement flexure (Figs. 2, and 3). We have analyzed the focal mechanism solutions recorded within the area (Giner, 1996; De Vicente et al., 1996; Andeweg et al., 1999; Carreño et al., 2008), according to the methodology proposed by De Vicente et al. (1996). The regional stress-field for the Iberian Peninsula is described in Herraiz et al. (2000) and Stich et al. (2006) and (2010). In these works the UTB stress-field is defined by SHMAX with NW-trending, in agreement to the works focused at the UTB by Giner (1996) and De Vicente et al. (1996) and, therefore, we have made a kinematic interpretation of the focal mechanisms. The focal mechanisms for earthquakes with $\mathrm{M}>3.4$ are (Andeweg et al., 1999): (a) reverse and normal faults oriented with NE-trending and (b) strike-slip faults with NW-trending (Fig. 10). Normal faults are coherent with the local stress tensor defined here (SHMAX NE-trending) and located at the extensional zone defined by the basement flexure. However, the focal mechanisms of reverse faulting obey the regional stress tensor (SHMAX NW-trending) and 
Fig. 7.- Photographs of faulting affecting fluvial sediments at the Jarama River and the Tagus River, located at the South of the Tagus Basin. (a) y (b) are reverse faulting activated by the regional stress tensor (SHMAX NW-trending), and (c) and (d) lateral and normal faulting activated by the local stress tensor (SHMAX NEtrending).

Fig.7.- Ejemplos de diferentes tipos de fallas afectando a materiales fluviales del río Jarama y del río Tajo en el sur de la cuenca: a) y b) fallas inversas decimétricas ( $\mathrm{SH}$ MAX NO-SE), c) fallas direccionales con componente normal y d) falla normal (ambas según SHMAX NE-SE, tensor local).
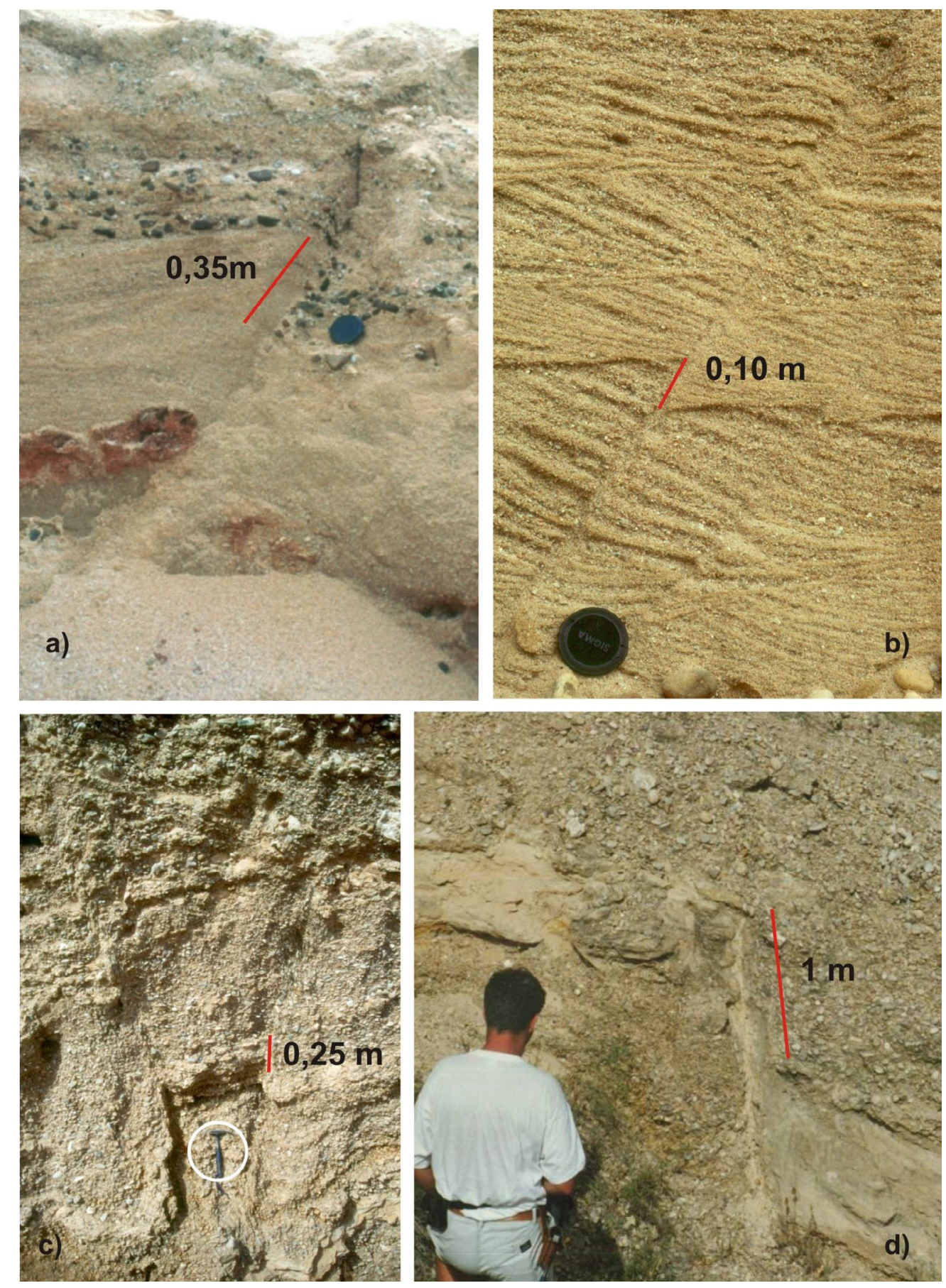

spatially located southward of the flexure zone.

The orthogonal relationship between the SHMAX orientation of the regional and local stress tensor points the same genetic relationship for both types of faulting, normal and reverse (Giner et al., 2003). This same genetic origin for both fault sets we assume that is due to the lithospheric folding and basement flexure, provoking a stress axes switch from the regional tensor (SHMAX NW-trending) to the local one (SHMAX NE-trending). Hence, normal faulting in this area works as the seismogenic source related to the flexure of the basement, restricted to the extensional zone of shallow and surface folding (Fig. 11) recognized by several authors on basis to the deformation of Late Neogene intrabasinal surfaces (Fernández-Casals, 1979; Silva et al., 1988; Alonso Zarza et al., 2004; De Vicente et al., 2007).

Reverse faulting with NW-trending are related with the regional stress-field and related with the basement flexure as well. Therefore, shallow normal faulting can be considered as earthquake sources at basin centre locations, whereas earthquakes related to reverse faulting can be produced at deeper crustal levels (Fig. 11). Addi- 

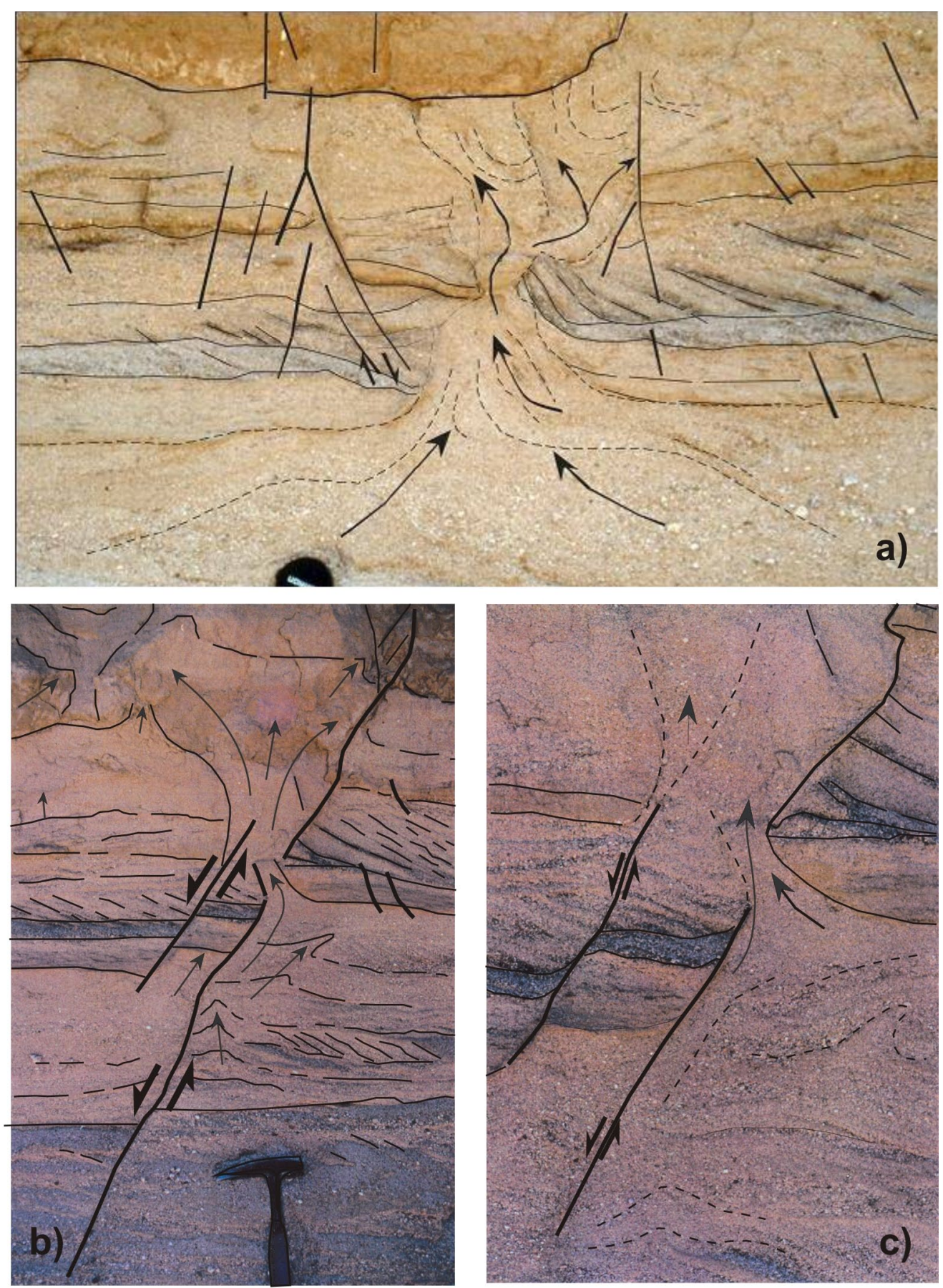

Fig. 8.- Liquefaction structures affecting Upper-Middle Pleistocene fluvial deposits located at the South of the UTB. (a) sand-dike liquefaction. (b) and (c) Sand liquefactions through minor normal faults, associated with the local stress tensor (Rodríguez-Pascua et al., 2000).

Fig. 8.- Ejemplos de estructuras de licuefacción en materiales de Pleistoceno medio superior en la zona sur de la cuenca. a) Estructura individual de licuefacción; b) y c) Estructura de licuefacción a asociada a pequeñas fracturas normales coherentes con el tensor de esfuerzos local ( $\mathrm{SH}$ MAX según NE-SO). Este tipo de estructuras se pueden asociar con paleoeventos con magnitudes entre 5.0 y 5.5 (RodríguezPascua et al., 2000). tionally the deformation is accommodated by strike-slips NE-trending at the NE part of the basin. These faults are transfer faults. The Escopete earthquake ( $7^{\text {th }}$ of June, 2007) (Carreño et al., 2008) was triggered by this type of faulting with a focal mechanism of sinistral lateral fault.

The second cluster of instrumental seismicity is located at the Southern border of the SCS (Fig. 10), though the major reverse faults (length $>100 \mathrm{~km}$ ) have no evidence of paleoseismicity and scarce record of instrumental seismicity. The earthquake cluster of the SCS is more related with strike-slip NW-trending. This fault set is similar to the strike-slips located at the northwestward of the basement flexure. Therefore, the major reverse fault of the South boundary of the SCS would not totally broke as a unique large segment (length $>100 \mathrm{~km}$ ) since it is segmented by crustal-scale transverse NW-strike-slip faults (Fig. 11). The scarce record and low magnitude of instrumental seismicity in this zone seems to support this seismotectonic scenario.The hyponcentre errors assumed in this work corresponds with focal mechanism solutions described in Andeweg et al. (1999). Since this work, only the Escopete earthquake (2007) has occurred within the 

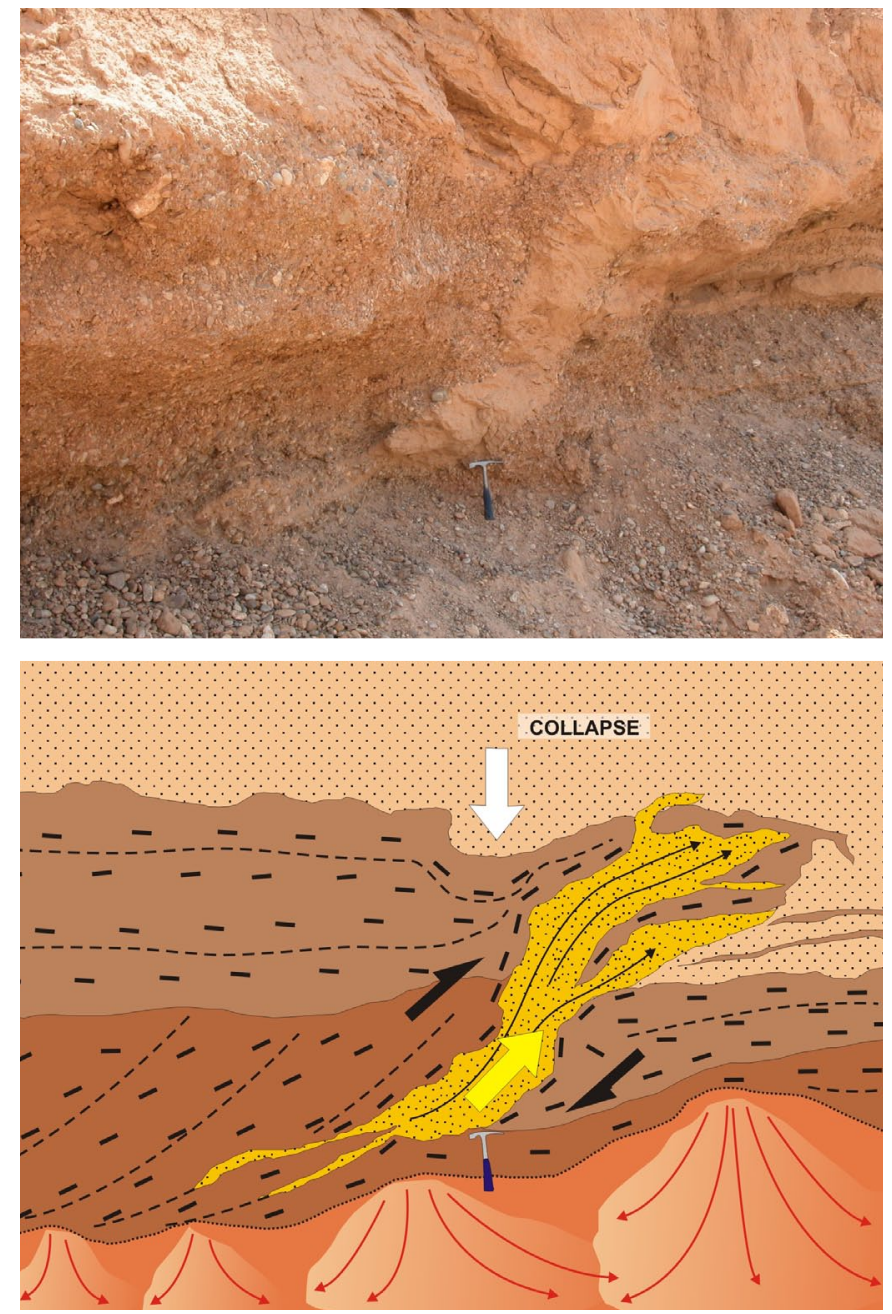

Fig. 9.- Liquefaction structure related with a reverse fault affecting fluvial deposits of the Middle Pleistocene. (Villarubia de Santiago, Toledo).

Fig. 9.- Estructura de licuefacción asociada a una falla inversa afectando a materiales del pleistoceno medio-superior en las proximidades de Villarrubia de Santiago (Toledo).

Madrid Basin with a minimum size to obtain the focal mechanism. Despite the scarce instrumental record to perform a statistical analysis to support the spatial distribution of earthquakes in depth, the flexure model fits enough to explain the present instrumental distribution of earthquakes within this basin.

\section{Discussion and conceptual model}

Summarizing, three different tectonic sources determine the intraplate tectonic field within the UTB and they may activate faults: (1) the tectonic far-field from the convergence between Africa, Iberia and Eurasia plates, plus the pushing of the MAOR (2) the lithosphere -mantle coupling by the lithospheric flexion evidenced by large basement wave-length folding and (3) the tectonic loading by the topography of the SCS. Therefore, the tectonic slip-rate estimated should be related with a strength balance of all of these tectonic driving forces.

The strain field observed into the UTB is defined by two different patterns (Fig. 2): (1) active normal and strikeslips faults, SHMAX NE-trending, parallel to the Tajuña River and morpho-lineaments with NE-trending, and (2) morpho-lineaments with NW-trending. Seismicity clusters are related with the second strain pattern. Both strain patterns are in agreement with the strain regime obtained from the structural analysis: (A) the regional strain tensor with SHMAX NW-trending, activating NE-reverse faults and NW-strike-slips faults, and (B) the local strain tensor defined by SHMAX NE-trending. This local tensor we assume a switch off the regional tensor due to the basement flexion, acting surface faulting with $10 \mathrm{~km}$ long and $11 \mathrm{~km}$ depth, normal NE-faults and lateral NW-faults.

Basement faults within the basin, as the South Border of the SCS, are well oriented according to the presentday NW-trending tectonic compression (De Vicente et al., 1996, 2007, 2009). What is the role of this basement faults as seismogenic-sources? Reactivation under the presentday stress field is possible within the most accepted tectonic framework, although the question emerges from the potential total energy accumulation of these faults, fed by the far-field stress transferred from the SE plate boundary. Taking into account that the bulk portion of the stress is released in the Betic Cordillera and another relevant fraction is derived for lithospheric folding and topographical loading, a minimum stress value can be stored at the Southern Border of the SCS. Following this assumption, $125 \mathrm{~km}$ of fault length (assuming a complete rupture of the fault of the South border of the SCS) and $16 \mathrm{~km}$ width (upper crust) should involve a lot of energy accumulation $\left(6.3110^{16} \mathrm{~J}\right)$ that could be released in a M8 earthquake (according to Wells and Coppersmith, 1994). No such sizedearthquakes have been evidenced along the paleoseismic record since the Middle Pleistocene ( 780 kyr B.P.), suggesting a minimum recurrence interval in the same timerange for expected earthquakes of M8, and independent of the fault segmentation for the SCS.

The basement flexure determines the spatial distribution of active faults in the Tagus Basin. The NE boundary of the flexure displays strike-slips faults with NE-trending and $20 \mathrm{~km}$ long (Fig. 11). The Escopete earthquake ( $7^{\text {th }}$, June of 2007) with magnitude mb 4.2 and $10 \mathrm{~km}$ depth occurred within this area. Maximum peak ground acceleration (PGA) was $0.07 \mathrm{~g}$, though the estimated maximum value for 400 years was $0.04 \mathrm{~g}$ (Carreño et al., 2008).

The analysis of the focal mechanism solutions for the scarce instrumental seismicity within the area (www. ign.es), namely in the surrounding of the flexure axis, reveals two fault geometries with NE-trending: reverse 


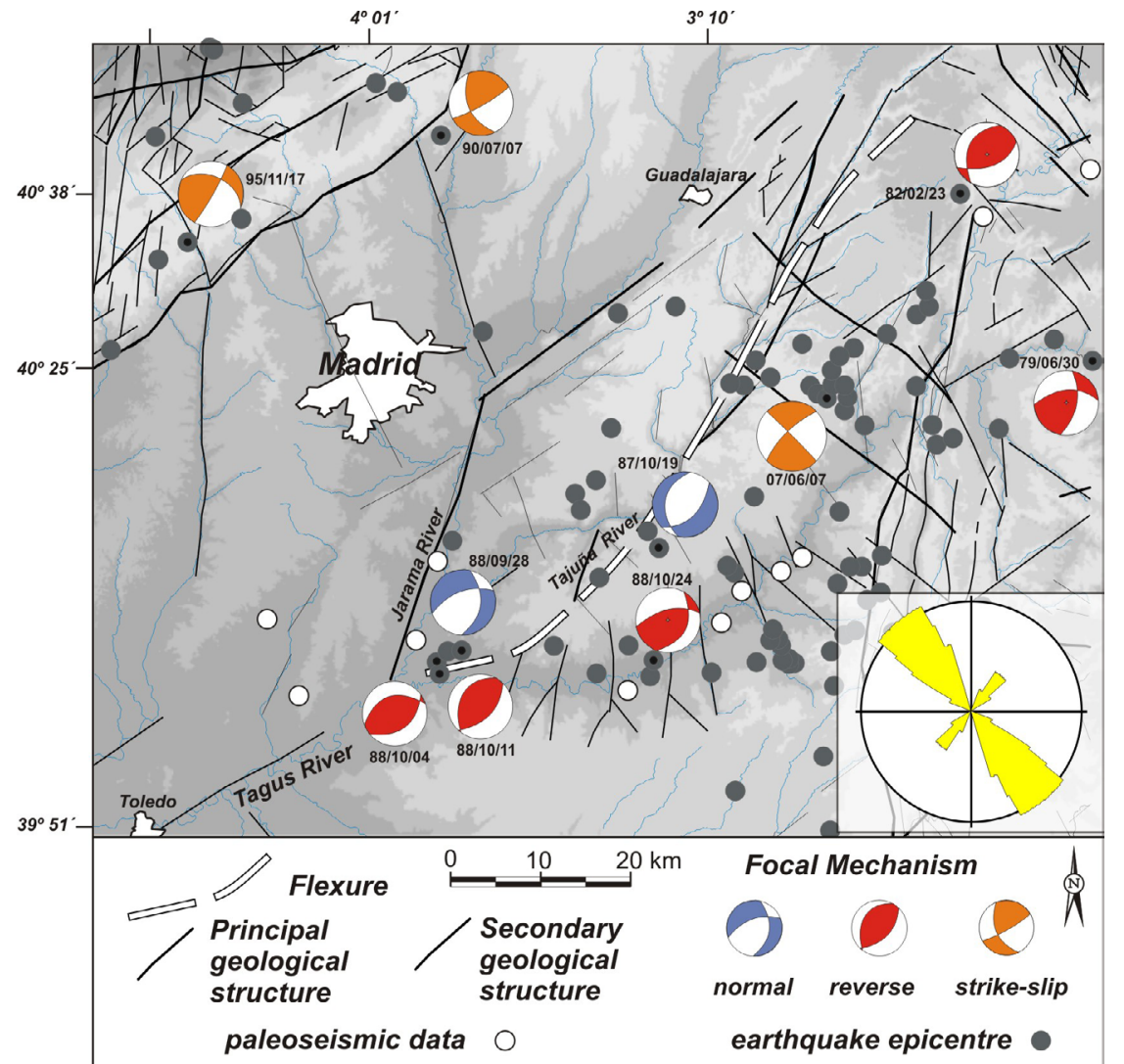

Fig. 10.- Focal mechanisms and instrumental seismicity within the Madrid Basin (Carreño et al., 2008) and paleoseismic sites. Rose diagram of the ey direction deduced from the focal mechanism solutions.

Fig. 10.- Situación de los epicentros y de los mecanismos focales (modificado de Carreño et al., 2008) y de las estructuras paleosísmicas localizadas en el área de estudio. Diagrama de orientaciones de máximo acortamiento horizontal (ey) deducido del análisis de los mecanismos focales.

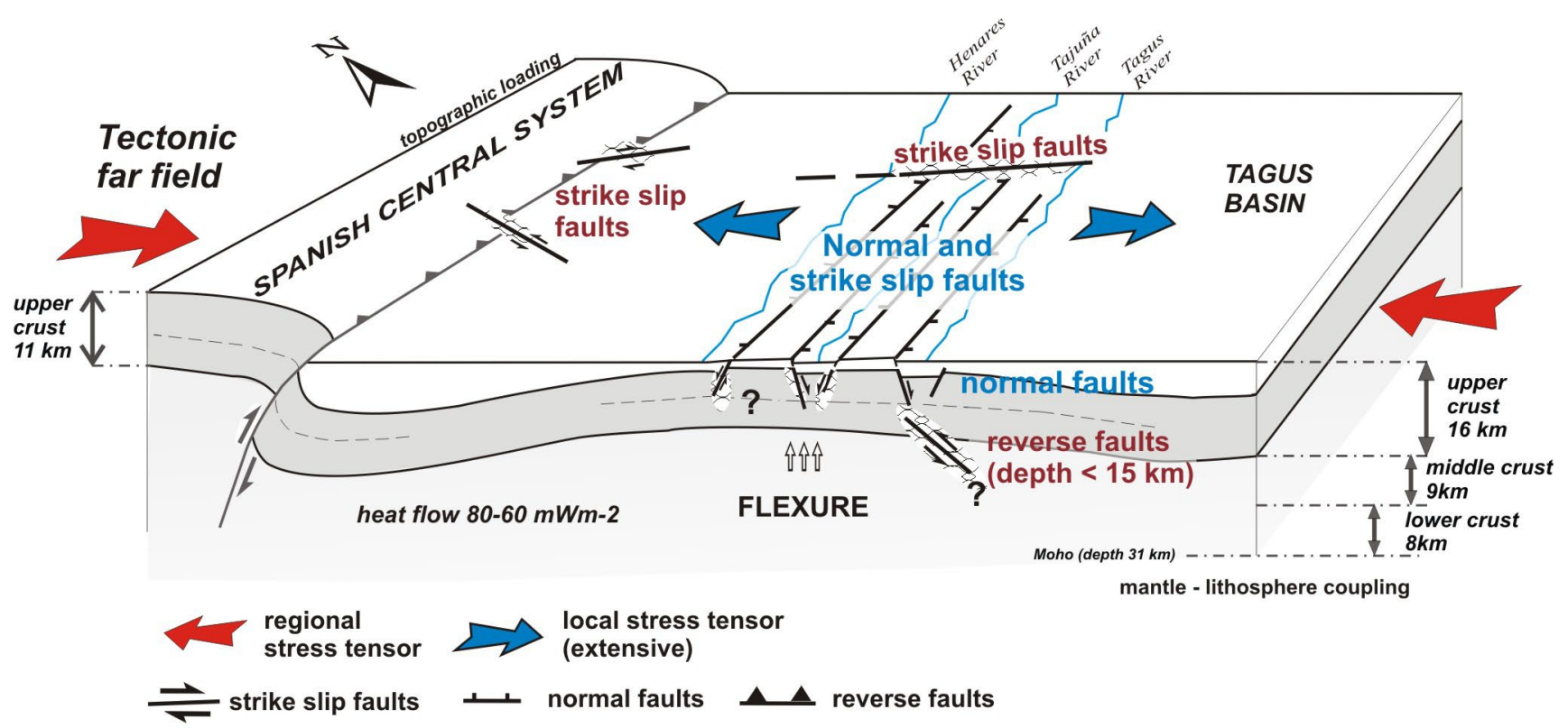

Fig. 11.- Tectonic sketch of the Upper Tagus Basin, showing the main seismic structures located at the Spanish Central System (SCS) and the Tagus Basin (TB). Despite the reverse faulting of the South border of the SCS is blocked as seismic source, minor strike slips could trigger low-magnitude earthquakes $(\mathrm{M}<6)$. Earthquakes within the TB would be associated with shallow $($ depth $<10 \mathrm{~km})$ normal faults and reverse faulting $(10>$ depth $>16 \mathrm{~km})$, constrained by the limit between the upper and middle crust. The earthquake magnitude for both types of faulting ranges between $5.5<\mathrm{M}<6.4$.

Fig. 11.- Esquema tectónico de la Cuenca Alta del Tajo, incluyendo el Sistema Central Español (SCS) y la Cuenca del Tajo (CT). A pesar de que la falla del borde sur del SCS parece estar bloqueada para grandes terremotos, las fallas en desgarre que sectorizan dicho cabalgamiento si podrían generar sismicidad aunque de magnitud moderada baja $(\mathrm{M}<6)$. En la cuenca del Tajo, los terremotos estarían asociados a fallas normales someras (profundidad $<10 \mathrm{~km}$ ) y a fallas inversas limitadas por el tránsito corteza superior-corteza media. En ambos casos la magnitud estaría comprendida entre $5.5<\mathrm{M}<6.4$. 
and normal faults. Despite the error of the hypocentral location for these earthquakes, we suggest the presence of a non-finite surface between the extensional (SHMAX NE-trending) and compresional (SHMAX NW-trending) zones. This implies that reverse earthquakes would be deeper than normal ones.

The reorganization of the fluvial network within the basin and the generation of large lineal canyon-shaped valleys at basin centre location date from Middle-Plesitocene (Silva et al., 1988, 1997), but paleoseismic evidence are characteristic until the last interglacial period (i.e. 125-90 kyr B.P., Silva, 2003). Vertical throws of 0.5 $\mathrm{m}$ recorded for the Late Pleistocene (125 kyrs), and empirical relationships used for paleoearthquakes and geometrical parameters of Quaternary faults (surface trace and width), suggest a tectonic slip-rate of $0.004 \mathrm{~mm} / \mathrm{yr}$, probably related to single isolated events. This value is too small and probably related with secondary faulting as to be considered as representative for the whole basin.

Finally, liquefaction structures affecting Late Pleistocene fluvial sediments indicate paleoevents with magnitudes greater than M5.5 and lesser than M6.5 (Rodríguez-Pascua et al., 2000; Silva et al., 2010). These sets of soft-sediment deformation features are associated principally with normal and lateral faults with NE-trending (local strain). This implies shallow normal-lateral earthquakes (depth $<10 \mathrm{~km}$ ) with a maximum size of M6.5.

\section{Conclusions}

The Upper Tagus Basin (UTB) is featured by two major tectonic structures:

The reverse fault of the South border of the Spanish Central System (SCS), with NE-trending, almost 100 $\mathrm{km}$ long and with no evidence of Quaternary and recent tectonic activity, according to the geomorphology within the area. Moreover, this fault displays a scarce and lowmagnitude instrumental seismicity for the historical plus the instrumental period (1911-2011), and mainly related with strike-slip faults (NW-trending), which divided and cross NE- reverse-faulting. Strike-slips have a maximum surface length of $8 \mathrm{~km}$.

Basement flexure determined by NE-trending axis and located underneath the Tagus Basin (TB). This zone is related with instrumental seismicity of magnitude maximum as M4.2 (Escopete earthquake, $7^{\text {th }}$ June of 2007), shallow normal earthquakes (depth $<10 \mathrm{~km}$ ) and located between the area bounded by the Tagus River and the Jarama River. This basement flexure is in agreement with the regional stress/strain tensor defined in this area by others authors (Giner et al., 1996; De Vicente et al., 1996; Herraiz et al., 2000; Tejero and Ruiz, 2002; De Vi- cente et al., 2007, 2009; Fernández-Lozano et al., 2011). Reverse earthquakes are deeper than normal earthquakes $(16 \mathrm{~km}>$ depth $>10 \mathrm{~km})$ in agreement with the geometry of the flexure and the strain field defined upper and down of the non deformation surface (strain deformation distribution in flexural folding with extrados/stretching and intrados/shortening). The interval of depth is according to the lower limit for the upper crust defined by Tejero and Ruiz (2002). However, new thermal models are required for describe the compressive and extensional distribution of the lithosphere within the Tagus Basin. Lateral NWtrending faults show low-magnitude instrumental seismicity (Carreño et al., 2008). Liquefaction structures for normal faulting indicate a paleoearthquake magnitudes between $5.5<\mathrm{M}<6.4$ for shallow normal faulting.

Analysis for the instrumental seismicity plus the major tectonic structures, suggest a tectonic slip-rate of 0.004 $\mathrm{mm} / \mathrm{yr}$ in this area. However, taking into account the geodynamic framework of the UTB, liquefaction structures and the empirical relationships between slip-rates and recurrence interval delivered by Villamor and Berryman (1999), we define the UTB as a stable intraplate area featured by Quaternary tectonic slip-rates $<0.02 \mathrm{~mm} / \mathrm{yr}$ for a time period of $125 \mathrm{Ka}$.

Taking into account that the studied area (UTB) includes large cities with a huge number of citizens, industrial and critical facilities (Madrid, Toledo, Guadalajara, Alcalá de Henares, etc.), it is necessary a full reevaluation of the potential seismic sources in the zone in order to be included in future seismic hazard analyses. In this sense, we suggest that such seismic sources are oriented bands of tectonic deformation at depth instead particular single large-faults as occur in plate margin locations. These bands of tectonic deformation account for most of the geomorphic anomalies in the studied area (i.e. Silva, 2003; De Vicente et al., 2007), Quaternary lineation and lineal Canyon-shaped valleys into the basin centre, as well as for the spatial clustering of instrumental seismicity. Potential damaging earthquakes $(\mathrm{M}>5.5)$ can be produced in the zone like events generated during the time-window of c.a. $780 \mathrm{kyr}$ and $125 \mathrm{kyr}$.

\section{Acknowledgement}

This work was partially supported by the Spanish projects MICINN FASEGEO: CGL2009-09726, IBERFAULT CGL2009-07388-E/BTE and the IGME-CSN IBERFAULT-2010. All data inhere were discussed under the project SHARE, Seismic Hazard Harmonization in Europe, of the Seventh Framework Program (FP7) of the European Commission (EC). This is a contribution of the QTECT-AEQUA Working Group. 


\section{References}

Alonso-Zarza, A.M., Calvo, J. P., Silva, P.G., Torres, T. (2004): La Cuenca del Tajo. In: J.A. Vera (ed.), Geología de España. Sociedad Geológica de España. SGE-IGME, Madrid: 556-561.

Andeweg B., G. De Vicente, S. Cloetingh, J. Giner, Muñoz-Martin, A. (1999): Local stress fields and intraplate deformation of Iberia: variations in spatial and temporal interplay of regional stress sources. Tectonophysics 305, 153-164. doi: 10.1016/S0040-1951(99)000049.

Babín-Vich, R. and Gómez-Ortiz, D. (1997): La tectónica Alpina en el borde norte del Sistema Central Español y su enlace con la Cuenca del Duero. Estudios Geológicos 53, 221-228. In Spanish. doi:10.3989/egeol.97535-6228.

Carreño, E., Benito, B., Martínez Solares, J. M., Cabañas, L., GinerRobles, J.L., Murphy, P., López, C., Del Fresno, C., Alcalde, J.M.. Gaspar-Escribano, J. M., Antón, J.G., Martínez-Díaz, J., Cesca, S., Izquierdo, A., Sánchez Cabañero, J.G. and Expósito, P. (2008): The June 7, $2007 \mathrm{mb}$ Lg 4.2 Escopete earthquake: an event with significant ground motion in a stable zone (Central Iberian Peninsula). Seismological Research Letters 79(6), 664-673. doi: 10.1785/ gssrl.79.6.820.

CSN-Consejo de Seguridad Nuclear (2007): Proyecto PRIOR: Determinación de fallas de primer orden en la Península Ibérica. Colección: Otros Documentos, 315 pp. In Spanish.

Cloetingh, S., E. Burov, F. Beekman, B. Andeweg, P. A. M. Andriessen, D. Garcia-Castellanos, G. de Vicente, and R. Vegas (2002): Lithospheric folding in Iberia. Tectonics 21(5), 1041, doi:10.1029/2001TC901031.

De Vicente, G., Giner-Robles, J.L., Muñoz-Martín, A., GonzalezCasado, J.M., Lindo, R. (1996): Determination of present-day tensor and neotectonic interval in the Spanish Central System and Madrid Basin, central Spain. Tectonophysics 266, 405- 424. doi:10.1016/ S0040-1951(99)00004-9.

De Vicente, G., Vegas, R., Muñoz-Martín, A., Silva, P.G., Andriessen, P., Cloetingh, S., González-Casado, J.M., Van Wees, J.D., Álvarez, J., Carbó, A., Olaiz, A. (2007): Cenozoic thick-skinned and topography evolution of the Spanish Central System. Global and Planetary Change 58, 335-381. doi: 10.1016/j.gloplacha.2006.11.042.

De Vicente, G., Vegas, R., Muñoz-Martín, A., Van Wees, J.D. CasasSáinz, A., Sopeña, A., Sánchez-Moya, Y., Arche, A., López-Gómez, J., Olaiz, A., Fernández-Lozano J. (2009): Oblique strain partitioning and transpression on an inverted rift: The Castilian Branch of the Iberian Chain. Tectonophysics 470, 224-242. doi:10.1016/j. tecto.2008.11.003.

Fernández-Casals, M.J. (1979): Las deformaciones hercínicas del límite somosierra-Guadarrama (Sistema Central). Estudios Geológicos 35, 169-191 In Spanish.

Fernández-Lozano, F., D. Sokoutis, E. Willingshofer, S. Cloetingh, G. De Vicente (2011): Cenozoic deformation of Iberia: A model for intraplate mountain building and basin development based on analogue modeling. Tectonics 30, TC1001, doi:10.1029/2010TC002719.

Giner, J. L. (1996): Análisis neotectónico y sisnotectónico en el sector centro-oriental de la Cuenca del Tajo. PhD. Thesis, Universidad Complutense de Madrid Madrid: 325 p. In Spanish.

Giner, J.L., de Vicente, G., Pérez González, A.C., Sánchez Cabañero, J.G., Pinilla, L. (1996): Crisis tectónicas cuaternarias en la Cuenca de Madrid. Geogaceta 20(4), 842-845. In Spanish.

Giner-Robles, J.L., González-Casado, J.M., Gumiel, P., GarcíaCuevas, C. (2003): Changes in strain trajectories in three different types of plate tectonic boundary deduced from earthquake focal mechanisms. Tectonophysics 372, 179-191. doi: 10.1016/S00401951(03)00310-X.
Gómez-Ortiz, D., Tejero-López, R. Babín-Vich, R. Rivas-Ponce, A. (2005): Crustal density structure in the Spanish Central System derived from gravity data analysis (Central Spain). Tectonophysics 403, 131- 149. doi:10.1016/j.tecto.2005.04.006

Hanks, T.C. Kanamori, H. (1979): A moment magnitude scale. Journal of Geophysical Research, 84(B5), 2348-2350. doi:10.1029/ JB084iB05p02145.

Herraiz, M., De Vicente,G., Lindo-Ñaupari, R., Giner Robles, J. L., Simón, J. L., González-Casado, J. M., Vadillo, O., Rodríguez -Pascua, M. A., Cicuéndez, J. I., Casas, A., Cabañas, L., Rincón, P., Cortés, A. L., Ramírez, M., Lucini, M. (2000): The recent (upper Miocene to Quaternary) and present tectonic stress distributions in the Iberian Peninsulañ. Tectonics 19(4), 762-786. doi:10.1029/2000TC900006.

Jiménez-Díaz, A., Ruiz, J. Villaseca, C. Tejero, R. Capote, R. (2012): The thermal state and strength of the lithosphere in the Spanish Central System and Tajo Basin from crustal heat production and thermal isostasy. Journal of Geodynamics 58, 29-37. doi: 10.1016/j. jog.2012.01.005.

Martín-Velázquez, S., De Vicente, G. Elorza, F.J. (2009): Intraplate stress state from finite element modelling: The southern border of the Spanish Central System. Tectonophysics 473, 417-427. doi:10.1016/j.tecto.2009.03.024.

Mooney, W.D., Laske, G. Master T.G. (1998): CRUST 5.1: A global crustal model at $5^{\circ} \times 5^{\circ}$. Journal of Geophysical Research 103, 727 747. doi:10.1029/97JB02122.

Obermeier, S.F. (1996): Use of liquefaction - induced features for paleoseismic analysis. An overview of how seismic liquefaction features can be distinguished from other features and how their regional distribution and properties of source sediment can be used to infer the location and strength of Holocene paleo - earthquakes. Engineering Geology 44, 1-76. doi:10.1016/S0013-7952(96)00040-3.

Pérez-López, R., Paredes, C., Muñoz-Martín, A. (2005): Relationship between the fractal dimension anisotropy of the spatial faults distribution and the paleostress fields on a Variscan granitic massif (Central Spain): the F-parameter. Journal of Structural Geology 27, 663-677. doi:10.1016/j.jsg.2005.01.002.

Reches, Z. (1987): Determination of the tectonic stress from slip along faults that obey the Coulomb yield condition. Tectonics 7, 849-861. doi:10.1029/TC006i006p00849.

Rodríguez Pascua, M.A., Calvo, J.P., De Vicente, G., Gómez Gras, D. (2000): Soft-sediment deformation structures interpreted as seismites in lacustrine sediments of the Prebetic Zone, SE Spain, and their potential use as indicators of earthquake magnitudes during the Late Miocene. Sedimentary Geology 135, 117- 135. doi:10.1016/ S0037-0738(00)00067-1.

Silva, P.G., Goy, J.L. Zazo, C. (1988): Neotectónica del sector centromeridional de la Cuenca de Madrid. Estudios Geológicos 44, 415427. In Spanish. doi:10.3989/egeol.88445-6558.

Silva, P.G., Cañaveras, J.C., Sánchez-Moral, S., Lario, J., Sanz, E. (1997): 3D soft-sediment deformation structures: evidence for Quaternary seismicity in the Madrid basin, Spain. Terra Nova 9, 208212. doi: 10.1111/j.1365-3121.1997.tb00014.x.

Silva, P.G. (2003): El Cuaternario del Valle Inferior del Manzanares. Estudios Geológicos 59, 107-131. doi:10.3989/egeol.03591-488. In Spanish.

Silva, P.G., Rodríguez-Pascua, M.A. Pérez-López, R. Giner-Robles, J.L. Roquero, E. Tapias, F. López Recio, M. Rus, I. Morin, J. (2010): Evidences of Paleoearthquakes in Palaeolithic settlements within fluvial sequences of the Tagus Basin (Madrid, Central Spain). Geophysical Research Abstracts. $7^{\text {th }}$ EGU General Assembly: Environmental hazards and Ancient Societies: Lessons from the Past? (Natural Hazard). Vienna. Austria: p.6061. 
Silva, P.G., Giner-Robles, J.L., Rodríguez-Pascua, M.A., PérezLópez, R. Roquero, E. (2011): Evidences of Late Pleistocene Paleoearthquakes within fluvial sequences around the Madrid City (Central Spain). XVIII INQUA-Congress: Session on Paleoseismology, megacities, and critical social infrastructures. Abstract n ${ }^{\circ} 1234$. Bern. Switzerland.

Stich, D., Serpelloni, E. Mancilla, F.L. Morales, J. (2006): Kinematics of the Iberia-Maghreb plate contact from seismic moment tensors and GPS observations. Tectonophysics 426, 295-317. doi:10.1016/j. tecto.2006.08.004.

Stich, D., Martín, R., Morales, J. (2010): Moment tensor inversion for Iberia-Maghreb earthquakes 2005-2008. Tectonophysics 483, 390-398. doi:10.1016/j.tecto.2009.11.006.
Suriñach, E., Vegas, R. (1988): Lateral inhomogeneities of the Hercyninan crust in central Spain. Physics of the Earth and Planetary Interiors 51, 226-234. doi:10.1016/0031-9201(88)90049-0.

Tejero R., J. Ruiz (2002): Thermal and mechanical structure of the central Iberian Peninsula lithosphere. Tectonophysics 350, 49-62. doi:10.1016/S0040-1951(02)00082-3.

Villamor, P., Berryman, K. (1999): La tasa de desplazamiento de una falla como aproximación de primer orden en las estimaciones de peligrosidad sísmica. $1^{\text {er }}$ Congreso Nacional de Ingeniería Sísmica, Murcia: 153-163. In Spanish.

Wells, D.L., Coppersmith, K.J. (1994): New empirical relationships among magnitude, rupture length, rupture width, rupture area, and surface displacement. Bulletin of the Seismological Society of America 84, 974-1002. 